\title{
INFLUENCE OF DIFFERENT CONSTANT TEMPERATURE DEGREES AND HOST PLANTS ON CERTAIN BIOLOGICAL ASPECTS OF THE MELON LADYBIRD BEETLE Epilachna chrysomelina (F.) (COLEOPTERA: COCCINELLIDAE) Awadalla, S. S. ; Horia A. Abdel-Wahab ${ }^{* *}$; N. F. Abd El-Baky and Shymaa S. Abdel-salam \\ * Economic Entomology Dept., Fac. Agric., Mans. Univ. ** Plant Protection Inst. Agric. Reas. Centre, Dokki, Giza.
}

\begin{abstract}
Laboratory experiments were carried out in the insectory of Economic Entomology Department,Faculty of Agriculture, Mansoura University, under three constant temperature $24 \pm 1,28 \pm 1$ and $32 \pm 1^{\circ} \mathrm{C}$ and $60.0 \pm 5 \%$ R.H.

The total duration of the immature stages were the shortest $(28.3 \pm 2.7$ days $)$ when the insect pest reared under constant temperature of $32 \pm 1^{\circ} \mathrm{C}$ followed by $(37.4 \pm$ 2.6 days) at $28 \pm 1^{\circ} \mathrm{C}$ and the longest period was recorded at $24 \pm 1^{\circ} \mathrm{C}$ and represented by ( $41.9 \pm 2.8$ days) with highly significant differences.

The highest percentages of hatchability, the survival of larval stage, pupal stage as well as the total immature stages were recorded when the insect reread at $28 \pm 1^{\circ} \mathrm{C}$ and represented by $95.0,88.4,97,6$ and $82 \%$, respectively. On the other hand, the lowest percentages were $87.0,78.2,95.7$ and $65 \%$ for hatching , the survival of larval stage, pupal stage and the total immature stages at $24 \pm 1^{\circ} \mathrm{C}$, respectively.

The ovipositional periods ( pre - oviposition period, oviposition period and inter - oviposition period ) as well as the female and male longevity were the shortest when the melon ladybird beetle reared at $32 \pm 1^{\circ} \mathrm{C}$ followed by $28 \pm 1^{\circ} \mathrm{C}$ and $24 \pm 1^{\circ} \mathrm{C}$ while , the fecundity ( average number of eggs / female ) were the highest at $28 \pm 1^{\circ} \mathrm{C}$ and represented by $743.0 \pm 25.8$ eggs / female and the lowest fecundity at $24 \pm 1^{\circ} \mathrm{C}$ and represented by $570.7 \pm 28.6$ eggs / female with highly significant differences.

The total duration of the immature stages were the shortest (37.4 2.6 days) when the insect pest reared on snake cucumber followed by (39.0 \pm 3.5 days) on squash, (39.5 \pm 2.7 days) and watermelon and the longest periods were recorded on cucumber and represented by ( $40.9 \pm 2.4$ days). Highly significant differences were recorded between the total duration of the immature stages reared at different host plants.

The highest percentages of hatchability, the survival of larval stage , pupal stage as well as the total immature stages were recorded when the insect reread on snake cucumber and represented by $95.0,88.4,97,6$ and $82 \%$, respectively. On the other hand, the lowest percentage were $89.0,72.1,93.7$ and $60 \%$ for hatching , the survival of larval stage, pupal stage and the total immature stages on cucumber, respectively.

The ovipositional periods ( pre - oviposition period , oviposition period and inter - oviposition period ) as well as the female and male longevity were the shortest when the melon ladybird beetle reared on snake cucumber followed by squash ,watermelon, and cucumber .While, the fecundity Were the highest on snake cucumber and represented by $743.0 \pm 25.8$ eggs / female and the lowest fecundity on cucumber and represented by $275.5 \pm 19.8$ eggs / female with highly significant differences according to the different host plants.
\end{abstract}




\section{INTRODUCTION}

The melon ladybird beetle, Epilachna chrysomelina F.(coleoptera: coccinellidae) is considered a serious pest of cucurbit plants in Egypt (Bohlen and freidel, 1979, Gameel 2004 and Gameel and Abdel-Gaid 2007and Sayed and Gameel 2008 ) and is widely distributed ( Ghabn, 1951, El-Saeady,1978, Ali and El- Saeady,1986 and Abdel-Moniem et al.,2004). Both larvae and adults cause great damage in a short time. Its feeding habits are phytophagous and injurious. It feeds on leaves, flowers and fruits of their host plants, belonging mainly to the family cucurbitaceae. The damage to the leaves reduces the vegetative production of the host-plant, but sometimes flours or even fruits are also destroyed. Leaves are skolotonized by feeding on the epiderm of one side, whereas that of the other side remains intact. Badly damaged leaves shrive and dry up. (Ali and El-saeady 1981 and 1986). Temperature and host plant are considered to be exogenous factors affecting insect development. Certain biological aspects of $E$. chrysomelina as has been studied in the present work were evidently influenced by these factors. (Ali and El-saeady 1981) .

Temperature and host plants are considered among the most important factors influencing the insect development. The effect of these factors on development, fecundity and the percentage of insect survival on different species were studied (Chen et al.,1989 on Epilachna Vigintioctopunctata (Fab); Elden (1991) on Epilachna Varivestis ; El- Abdin and Siraglnour (1991) on Epilachna elaterii (Rossi); Fan et al., (1992) on E. Varivestis ;patel and purohit (2000) on E. Vigintioctopunctata and Takeuchi et al., (2008) on Epilachna admirabilis .

The present study aimed to throw the light on the influence of different constant temperature degrees as well as the different host plants on certain biological aspects of the melon lady bird beetle.

\section{MATERIALS AND METHODS}

\section{* Influence of different constant temperature degrees:-}

Laboratory experiments were carried out in the Insectary of Economic Entomology Department, Faculty of Agriculture, Mansoura University under three constant temperature $24 \pm 1,28 \pm 1$ and $32 \pm 1^{\circ} \mathrm{C}$.

To obtain a culture from the melon ladybird beetle E. chrysomelina F., a large number of the insect pest in the pupal stage were collected from snake cucumber and transferred to the laboratory until emergence to the adults. Newly emerged females and males kept in Petri dishes $(9-\mathrm{cm}$ diameter) and provided with a fresh leaves of snake cucumber until mating and female egg-laying. Newly deposited eggs were divided into three groups. Each group of the egg was kept in Petri dishes (9-cm diameter) at one of the following constant temperature degrees $24 \pm 1,28 \pm 1$ and $32 \pm 1{ }^{\circ} \mathrm{C}$ as well as $60.0 \pm 5.0 \%$ R.H. and photoperiod 14:10 (L:D) and monitored until hatching . The hatched larvae were reared individually in Petri dishes (9-cm diameter) in the incubator under the three constant temperatures $24 \pm 1,28 \pm 1$ and $32 \pm 1^{\circ} \mathrm{C}$ 
and provided with a fresh leaves of snake cucumber daily. Each larva was considered as a replicate (20 replicates for each constant temperature). A piece of filters paper was placed on the bottom of each dish to provide a walking surface for the larvae.

The duration of the immature stages ( eggs, larvae, pupae ) of the insect were recorded and calculated as well as the survival from eggs to adult eclosion were calculated under the three constant temperature degrees.

To determine the ovipositional periods, adult longevity for females and males, fecundity and fecundity rate of the melon ladybird beetle in relation to different temperatures, newly emerged adults were paired in Petri dishes (9$\mathrm{cm}$ diameter). Each pair was provided with a fresh leaves of snake cucumber. Ten pairs considered as a replicates for each constant temperature degree. Statistical analysis was carried out by using one way ANOVA.

* Influence of different host plants:-

Experiments were carried out in the Insectary under three constant temperature $28 \pm 1^{\circ} \mathrm{C}$ and $60.0 \pm 5.0 \%$ R.H. and photoperiod $14: 10$ (L:D) .To obtain a culture from the melon ladybird beetle $E$. chrysomelina, a large numbers of the insect pest in the pupal stage were collected from cucurbit vegetables as squash, cucumber, snake cucumber and watermelon and transferred to the laboratory until emergence to the adults. Newly emerged females and males kept in Petri dishes $(9 \mathrm{~cm}$ diameter) and provided with a fresh leaves of cucurbit vegetables until mating and female egg-laying. Newly deposited eggs were divided into four groups. Each group was kept in Petri dishes (9- $\mathrm{cm}$ diameter) until hatching. The hatched larvae were reared individually in Petri dishes (9-cm diameter) in the incubator. Each larva was considered as a replicate ( 20 replicates for each treatment). Each treatment was provided with a fresh leaves of cucurbit as squash, cucumber, snake cucumber and watermelon as a different host plants. A piece of filters paper was placed on the bottom of each dish to provide a walking surface for the larvae.

The duration of the immature stages ( eggs, larvae, pupae ), the survival percentage as well as the ovipositional periods, adult longevity for females and males, fecundity and fecundity rate for different host plants were calculated as previously mentioned in influence of different constant temperature degrees.

\section{RESULTS AND DISCUSSION}

\section{Influence of different constant temperature degrees:-}

Data illustrated in Table (1) showed the influence of different constant temperature degrees $24 \pm 1,28 \pm 1$ and $32 \pm 1^{\circ} \mathrm{C}$ on the immature stages (incubation period, the larval stage and the pupal stage) of the melon ladybird beetle $E$. chrysomelina reared on snake cucumber.

It can be noticed that , at $32 \pm 1^{\circ} \mathrm{C}$, the incubation period $(5.6 \pm 0.8)$, the larval stage $(15.6 \pm 1.8)$ and the pupal stage $(6.1 \pm 0.6$ days $)$ were the shortest followed by $28 \pm 1^{\circ} \mathrm{C}$ and represented by $(6.6 \pm 0.9,20.3 \pm 2.2,10.5$ 
\pm 0.6 days) and the constant temperature $24 \pm 1^{\circ} \mathrm{C}$ was the longest and represented by $(7.1 \pm 0.9,23.0 \pm 1.6$, and $11.8 \pm 0.8$ days $)$ for incubation period, larval stage and pupal stage, respectively .

As a conclusion, data arranged in Table (1) indicated that, the total duration of the immature stages was the shortest ( $28.3 \pm 2.7$ days) when the insect pest reared under constant temperature $32 \pm 1^{\circ} \mathrm{C}$ followed by $(37.4 \pm 2.6$ days) at $28 \pm 1^{\circ} \mathrm{C}$ and the longest periods were recorded at $24 \pm 1^{\circ} \mathrm{C}$ and represented by $(41.9 \pm 2.8$ days $)$. Highly significant differences were recorded between the incubation period, larval stage or pupal stage at different temperature treatments. Similar observations were reported by Ali and El-Saeady (1981) and Chen et al (1989).

Table (1): Influence of different constant temperature degrees on the immature stages of $E$. chrysomelina reared on snake cucumber.

\begin{tabular}{|c|c|c|c|}
\hline \multirow{2}{*}{ Biological aspects } & \multicolumn{3}{|c|}{ Temperature } \\
\hline & $24^{\circ} \mathrm{C} \pm 1$ & $28^{\circ} \mathrm{C} \pm 1$ & $32 \stackrel{\circ}{ } \mathrm{C} \pm 1$ \\
\hline Incubation period & $7.1 \pm 0.9 a$ & $6.6 \pm 0.9 \mathrm{ab}$ & $5.6 \pm 0.8 b$ \\
\hline \multirow{5}{*}{\begin{tabular}{|l|} 
Larval \\
stage
\end{tabular}} & $6.2 \pm 0.6 \mathrm{a}$ & $5.6 \pm 0.8 \mathrm{a}$ & $4.3 \pm 0.5 \mathrm{~b}$ \\
\hline & $6.0 \pm 0.7 \mathrm{a}$ & $4.5 \pm 0.5 b$ & $3.7 \pm 0.8 b$ \\
\hline & $5.1 \pm 0.6 \mathrm{a}$ & $4.8 \pm 0.9 \mathrm{a}$ & $4.4 \pm 0.6 \mathrm{a}$ \\
\hline & $5.7 \pm 0.9 \mathrm{a}$ & $5.4 \pm 0.6 \mathrm{a}$ & $4.2 \pm 0.6 b$ \\
\hline & $23.0 \pm 1.6 \mathrm{a}$ & $20.3 \pm 2.2 \mathrm{~b}$ & $15.6 \pm 1.8 \mathrm{c}$ \\
\hline \multirow{4}{*}{$\begin{array}{l}\text { Pupal } \\
\text { stage }\end{array}$} & $3.9 \pm 0.8 \mathrm{a}$ & $3.1 \pm 0.3 \mathrm{ab}$ & $2.4 \pm 0.6 \mathrm{~b}$ \\
\hline & $7.9 \pm 0.8 \mathrm{a}$ & $7.4 \pm 0.7 \mathrm{a}$ & $3.7 \pm 0.8 b$ \\
\hline & $11.8 \pm 0.8 \mathrm{a}$ & $10.5 \pm 0.6 \mathrm{~b}$ & $6.1 \pm 0.6 \mathrm{c}$ \\
\hline & $41.9 \pm 2.8 \mathrm{a}$ & $37.4 \pm 2.6 \mathrm{~b}$ & $28.3 \pm 2.7 \mathrm{c}$ \\
\hline
\end{tabular}

significantly different at $1 \%$ level of probability (one way ANOVA).

Data arranged in Table (2) indicated that, the percentage of hatchability was the highest $95.0 \%$ at $28 \pm 1^{\circ} \mathrm{C}$ followed by $93.0 \%$ at $32 \pm 1^{\circ} \mathrm{C}$ and the lowest $87.0 \%$ at $24 \pm 1^{\circ} \mathrm{C}$.

The survival percentages of larval instars and pupal stage were the highest at $28 \pm 1^{\circ} \mathrm{C}$ and represented by $95.8,96.7,97.7,97.7$ and $97.6 \%$ for $1^{\text {st }}, 2^{\text {nd }}, 3^{\text {rd }}, 4^{\text {th }}$ larval instars and pupal stage , respectively. Meanwhile the lowest survival percentages were recorded when the insect reared at $24 \pm 1^{\circ} \mathrm{C}$ and represented by $92.0,93.8,94.7,95.8$ and $95.7 \%$ for the four larval instars and pupal stage, respectively.

As a conclusion, data represented in Table (2) indicated that, the highest percentages of hatchability, the survival of larval stage, pupal stage as well

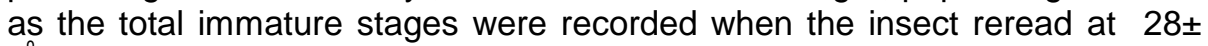
$1^{\circ} \mathrm{C}$ and represented by $95.0,88.4,97,6$ and $82 \%$, respectively. On the other hand, the lowest percentage were $87.0,78.2,95.7$ and $65 \%$ for hatching, the survival of larval stage, pupal stage and the total immature stages at $24 \pm 1^{\circ} \mathrm{C}$, respectively. These results are in agreement with those of Fan et al (1992). 
Table (2): Influence of different constant tempreture degrees on the survival percentages of $E$. chrysomelina reared on snake cucumber

\begin{tabular}{|c|c|c|c|}
\hline \multirow{2}{*}{ Biological Aspects } & \multicolumn{3}{|c|}{ Temperature } \\
\hline & $24^{\circ} \mathrm{C} \pm 1$ & $28 \stackrel{\circ}{C} \pm 1$ & $32 \stackrel{\circ}{ } \mathrm{C} \pm 1$ \\
\hline Hatchability\% & 87.0 & 95.0 & 93.0 \\
\hline $1^{\text {st }}$ instar & 92.0 & 95.8 & 94.6 \\
\hline $2^{\text {nd }}$ instar & 93.8 & 96.7 & 95.5 \\
\hline 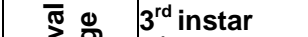 & 94.7 & 97.7 & 96.4 \\
\hline 政 $4^{\text {th }}$ instar & 95.8 & 97.7 & 96.3 \\
\hline コ் & 78.2 & 88.4 & 83.9 \\
\hline Pupal Stage & 95.7 & 97.6 & 97.4 \\
\hline Total immature stages & $65 \%$ & $82 \%$ & $76 \%$ \\
\hline
\end{tabular}

Data represented in Table (3) showed the effect of different constant temperature degrees $24 \pm 1,28 \pm 1$ and $32 \pm 1^{\circ} \mathrm{C}$ on the ovipositional periods , adult longevity for females and males as well as fecundity and fecundity rate of the melon ladybird beetle $E$. chrysomelina reared on snake cucumber. It can be noticed that, pre - oviposition period, oviposition period, inter oviposition period, female longevity and male longevity were the shortest when the insect were reared at $32 \pm 1^{\circ} \mathrm{C}$ and represented by $2.5 \pm 0.6,18.4 \pm$ $2.7,3.8 \pm .06,24.7 \pm 3.7$ and $19.8 \pm 2.7$ days , respectively. On the other hand, these periods were the shortest when the insect reared at $24 \pm 1{ }^{\circ} \mathrm{C}$ and represented by $5.5 \pm 1.6,32.6 \pm 3.7,9.5 \pm 1.5,47.6 \pm 4.6,40.5 \pm 3.9$ days ,respectively. Moreover, the fecundity of the insect female (the average number of eggs / female) were the highest $(743.0 \pm 25.8 \mathrm{eggs} /$ female $)$ were recorded at $28 \pm 1^{\circ} \mathrm{C}$ followed by $(690.0 \pm 33.7$ eggs/ female $)$ at $32 \pm 1^{2} \mathrm{C}$ and the lowest fecundity $(570.7 \pm 28.6$ eggs/ female) were recorded when the insect reared at $24 \pm 1^{\circ} \mathrm{C}$, while the fecundity rate were the highest $38.3 \pm 2.3$ eggs/ female / day at $32 \pm 1^{\circ} \mathrm{C}$ followed by $29.7 \pm 1.6 \mathrm{eggs} /$ female / day at $28 \pm$ $1^{\circ} \mathrm{C}$ and $17.8 \pm 1.7 \mathrm{eggs} /$ female / day when the insect reared at $24 \pm 1^{-} \mathrm{C}$.

Table (3): Influence of different constant temperature degrees on the ovi position period, adult longevity and the fecundity of $E$. chrysomelina reared on snake cucumber.

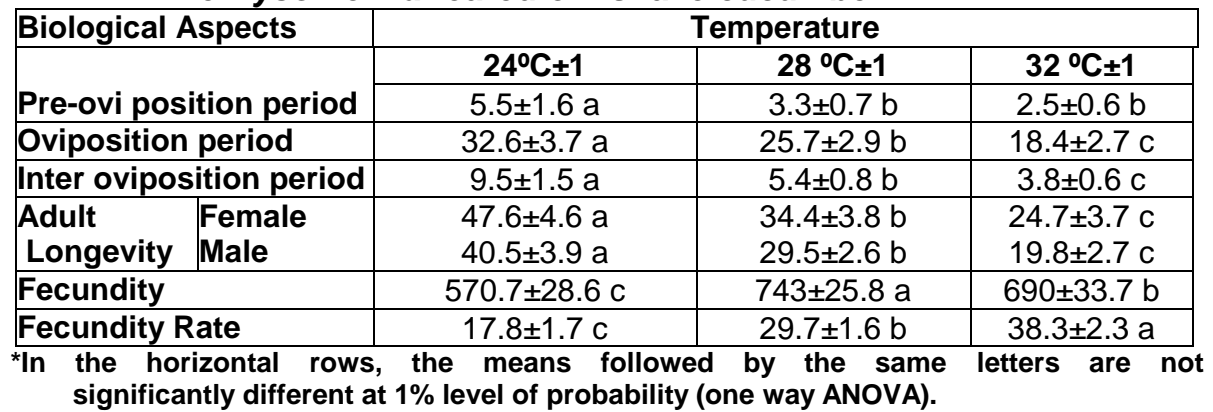

It can be concluded that, the ovipositional periods ( pre - oviposition period, oviposition period and inter - oviposition period ) as well as the female and male longevity were the shortest when the melon ladybird beetle 
reared at $32 \pm 1^{\circ} \mathrm{C}$ followed by $28 \pm 1{ }^{\circ} \mathrm{C}$ and $24 \pm 1^{\circ} \mathrm{C}$. while , the fecundity (average number of eggs / female) were the highest at $28 \pm 1{ }^{\circ} \mathrm{C}$ and represented by $743.0 \pm 25.8$ eggs / female and the lowest fecundity at $24 \pm 1^{\circ} \mathrm{C}$ and represented by $570.7 \pm 28.6$ eggs / female .

Statistical analysis revealed that, a highly significant differences were recorded between these biological aspects at different temperature treatments. these results are in agreement with those of El-Abdin and Siragelnour(1991).

* Influence of different host plants:-

Data illustrated in Table (4) showed the influence of different host plants as squash, cucumber, snake cucumber and watermelon on the immature stages of the melon ladybird beetle $E$. chrysomelina reared under laboratory condition $\left(28^{\circ} \mathrm{C}\right.$ and $60.0 \pm 5.0 \%$ R.H $)$

It can be noticed that, at snake cucumber, the larval stage $(20.3 \pm$ 2.2) and the pupal stage (10.5 \pm 0.6 days ) were the shortest followed by squash and represented by (21.8 \pm 1.7 and $11.1 \pm 0.5$ days), watermelon ( $22.0 \pm 2.3$ and $11.0 \pm 0.7$ ) and the longest period on cucumber and represented by $(23.2 \pm 2.6$, and $11.7 \pm 0.7$ days $)$ for larval stage and pupal stage, respectively .

As a conclusion, data arranged in Table (4) indicated that, the total duration of the immature stages were the shortest (37.4 2.6 days) when the insect pest reared on snake cucumber followed by (39.0 \pm 3.5 days) on squash, watermelon (39.5 \pm 2.7 days) and the longest periods were recorded on cucumber and represented by $(40.9 \pm 2.4$ days $)$. Highly significant differences were recorded between the total duration of the immature stages reared at different host plants. The obtained data are in agreement with those of Ali and El-saedy (1981) and (1986).

Table (4) : Influence of different host plants on the immature stages of E.chrysomelina reared under laboratory condition $\left(28 c^{\circ}\right.$ and $60 \pm 5 \%$ R.H)

\begin{tabular}{|l|c|c|c|c|c|}
\hline \multicolumn{2}{|l|}{ Biological Aspects } & Squash & Cucumber & $\begin{array}{c}\text { Snake } \\
\text { cucumber }\end{array}$ & Watermelon \\
\hline Incubation period & $6.3 \pm 0.5 \mathrm{a}$ & $6.7 \pm 0.89 \mathrm{a}$ & $6.6 \pm 0.63 \mathrm{a}$ & $6.5 \pm 0.55 \mathrm{a}$ \\
\hline \multirow{3}{*}{$\begin{array}{c}\text { Larval } \\
\text { Stage }\end{array}$} & $\mathbf{1}^{\text {st }}$ instar & $5.8 \pm 0.9 \mathrm{a}$ & $5.9 \pm 0.7 \mathrm{a}$ & $5.6 \pm 0.8 \mathrm{a}$ & $5.8 \pm 0.4 \mathrm{a}$ \\
& $\mathbf{3}^{\text {rd }}$ instar & $4.6 \pm 0.6 \mathrm{~b}$ & $5.6 \pm 0.6 \mathrm{a}$ & $4.5 \pm 0.5 \mathrm{~b}$ & $5.3 \pm 0.7 \mathrm{a}$ \\
& $\mathbf{4}^{\text {th }}$ instar & $6.4 \pm 0.4 \mathrm{ab}$ & $5.9 \pm 0.5 \mathrm{a}$ & $4.4 \pm 0.9 \mathrm{~b}$ & $5.5 \pm 0.6 \mathrm{a}$ \\
& Total & $21.8 \pm 1.7 \mathrm{a}$ & $23.2 \pm 2.6 \mathrm{a}$ & $20.3 \pm 2.2 \mathrm{~b}$ & $22 \pm 2.3 \mathrm{a}$ \\
\hline \multirow{2}{*}{$\begin{array}{l}\text { Pupal } \\
\text { Stage }\end{array}$} & Pre-pupa & $3.2 \pm 0.8 \mathrm{a}$ & $3.4 \pm 0.4 \mathrm{a}$ & $3.1 \pm 0.3$ & $3.3 \pm 0.7 \mathrm{a}$ \\
& pupa & $7.9 \pm 0.5 \mathrm{a}$ & $8.3 \pm 0.8 \mathrm{a}$ & $7.4 \pm 0.7 \mathrm{a}$ & $7.7 \pm 0.8 \mathrm{a}$ \\
\hline
\end{tabular}

Data arranged in Table (5) indicated that, the percentage of hatchability was the highest $95.0 \%$ on snake cucumber followed by $93.0 \%$ on squash followed by $91.5 \%$ on watermelon and the lowest $89.0 \%$ on cucumber . 
The survival percentages of larval instars and pupal stage were the highest on snake cucumber and represented by 95.8, 96.7, 97.7, 97.6 and $97.6 \%$ for $1^{\text {st }}, 2^{\text {nd }}, 3^{\text {rd }}, 4^{\text {th }}$ larval instars and pupal stage, respectively. Meanwhile the lowest survival percentages were recorded when the insect reared on cucumber and represented by $89.8,91.2,93.2,92.6$ and $93.7 \%$ for the four larval instars and pupal stage , respectively.

As a conclusion, data represented in Table (5) indicated that, the highest percentages of hatchability, the survival of larval stage, pupal stage as well as the total immature stages were recorded when the insect reread on snake cucumber and represented by $95.0,88.4,97,6$ and $82 \%$, respectively. On the other hand, the lowest percentages were $89.0,72.1,93.7$ and $60 \%$ for hatchability, the survival of larval stage, pupal stage and the total immature stages on cucumber, respectively.

Table (5): Influence of different host plants on the survival percentages of E.chrysomelina reared under laboratory condition $\left(28^{\circ} \mathrm{C}\right.$ and $60 \pm 5 \%$ R.H)

\begin{tabular}{|c|c|c|c|c|}
\hline \multirow[b]{2}{*}{ Biological Aspects } & \multicolumn{4}{|c|}{ Cucurbit Hosts } \\
\hline & Squash & Cucumber & $\begin{array}{c}\text { Snake } \\
\text { Cucumber }\end{array}$ & Watermelon \\
\hline Hatchability $\%$ & 93.0 & 89.0 & 95.0 & 91.5 \\
\hline $1^{\text {st }}$ instar & 93.5 & 89.8 & 95.8 & 92.3 \\
\hline $2^{\text {nd }}$ instar & 94.2 & 91.2 & 96.7 & 93.1 \\
\hline $\bar{\pi} \circlearrowleft 3^{\text {rd }}$ instar & 96.3 & 93.2 & 97.7 & 94.9 \\
\hline 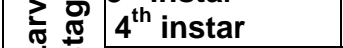 & 96.2 & 92.6 & 97.6 & 93.2 \\
\hline בn Total & 81.7 & 72.1 & 88.4 & 76.1 \\
\hline Pupal Stage & 96.5 & 93.7 & 97.6 & 95.6 \\
\hline Total immature stages & $73 \%$ & $60 \%$ & $82 \%$ & $67.5 \%$ \\
\hline
\end{tabular}

Data represented in Table (6) showed the influence of different host plant on the ovipositional periods, adult longevity for females and males as well as fecundity and fecundity rate of the melon ladybird beetle $E$. chrysomelina reared under laboratory condition $\left(28{ }^{\circ} \mathrm{C}\right.$ and $\left.60.0 \pm 5.0 \% \mathrm{R} . \mathrm{H}\right)$. It can be noticed that, pre - oviposition period, oviposition period, inter oviposition period, female and male longevity were the shortest when the insect were reared on snake cucumber and represented by $3.3 \pm 0.7,25.7 \pm$ $2.9,5.4 \pm 0.6,33.4 \pm 3.8$ and $29.5 \pm 2.6$ days, respectively. On the other hand, these periods were the longest when the insect reared on cucumber and represented by $8.5 \pm 0.7,18.3 \pm 1.8,9.5 \pm 0.7,36.3 \pm 3.2$ and $30.5 \pm 2.2$ days, respectively. Moreover, the fecundity of the insect female were the highest $(743.0 \pm 25.8$ eggs/ female $)$ were recorded on snake cucumber followed by (428.6 \pm 24.7 eggs/ female ) on squash , (350.8 \pm 18.9 eggs/ female) on water melon and the lowest fecundity (275.5 \pm 19.8 eggs/ female) were recorded when the insect reared on cucumber, while the fecundity rate were the highest $29.7 \pm 1.6$ eggs/ female / day on snake cucumber followed by $20.02 \pm 1.8 \mathrm{eggs} /$ female / day on squash and $17.9 \pm 1.5 \mathrm{eggs} /$ female / day when the insect reared on watermelon and the lowest rate $15.1 \pm 1.4$ eggs/ female / day on cucumber. 
It can be concluded that, the ovipositional periods ( pre - oviposition period, oviposition period and inter - oviposition period ) as well as the female and male longevity were the shortest when the melon ladybird beetle reared on snake cucumber followed by squash, watermelon and cucumber . while, the fecundity were the highest on snake cucumber and represented by $743.0 \pm 25.8$ eggs / female and the lowest fecundity on cucumber and represented by $275.5 \pm 19.8$ eggs / female .

Statistical analysis revealed that, a highly significant differences were recorded between these biological aspects at different host plant treatments . these results are in agreement with those of Ali and El-Saeady 1981 and 1986 and Patel and Purohit 2000.

Table (6): Influence of different host plants on the ovi position period, adult longevity and the fecundity of $E$. chrysomelina reared under laboratory condition ( $28 c^{\circ}$ and $\left.60 \pm 5 \% R . H\right)$.

\begin{tabular}{|c|c|c|c|c|}
\hline \multirow[b]{2}{*}{ Biological Aspects } & \multicolumn{4}{|c|}{ Cucurbit Hosts } \\
\hline & Squash & Cucumber & $\begin{array}{c}\text { Snake } \\
\text { cucumber }\end{array}$ & Watermelon \\
\hline Pre- ovi position period & $5.2 \pm 0.63 \mathrm{c}$ & $8.5 \pm 0.7 \mathrm{a}$ & $3.3 \pm 0.7 \mathrm{~d}$ & $7.3 \pm 0.8 \mathrm{~b}$ \\
\hline Ovi position period & $21.4 \pm 2.1 \mathrm{~b}$ & $18.3 \pm 1.8 \mathrm{~d}$ & $25.7 \pm 2.9 \mathrm{a}$ & $19.6 \pm 2.4 \mathrm{c}$ \\
\hline Inter ovi position period & $7.5 \pm 0.6 \mathrm{~b}$ & $9.5 \pm 0.7 \mathrm{a}$ & $5.4 \pm 0.6 \mathrm{c}$ & $8.3 \pm 0.7 b$ \\
\hline \begin{tabular}{|l|l|} 
Adult & Female \\
longevity & Male \\
\end{tabular} & $\begin{array}{l}34.1 \pm 3.9 \mathrm{c} \\
27.3 \pm 1.9 \mathrm{c}\end{array}$ & $\begin{array}{l}36.3 \pm 3.2 \mathrm{a} \\
30.5 \pm 2.2 \mathrm{a}\end{array}$ & $\begin{array}{l}33.4 \pm 3.8 \mathrm{c} \\
29.5 \pm 2.6 \mathrm{~b}\end{array}$ & $\begin{array}{l}35.2 \pm 3.7 b \\
29.1 \pm 2.1 b\end{array}$ \\
\hline Fecundity & $428.6 \pm 24.7 \mathrm{~b}$ & $275.5 \pm 19.8 \mathrm{~d}$ & $743 \pm 25.8 \mathrm{a}$ & $350.8 \pm 18.9 \mathrm{c}$ \\
\hline Fecundity Rate & $20.02 \pm 1.8 \mathrm{~b}$ & $15.05 \pm 1.4 \mathrm{~d}$ & $29.7 \pm 1.6 \mathrm{a}$ & $17.9 \pm 1.5 \mathrm{c}$ \\
\hline
\end{tabular}

\section{REFERENCES}

Abdel-Moniem, A. S. H., Gomaa, A. A., Dimetry, N. Z. T. Wetzel and C. Volkmar. (2004) Laboratory evaluation of certain compounds against the melon ladybird, Epilachna chrysomelina F. attacking cucurbit plants. Arch. phytopathol and plant protection. 37:71-81.

Ali, M. A and A. A. El-Saeady (1981). Influence of temperature, photoperiod and host-plant on the bionomics of the melon ladybird Epilachna chrysomelina (F.) (Coleoptera: Coccinellidae). Z.ang.Ent. 91(3): 256262.

Ali, M. A. and A. A. El-Saeady (1986): Phenology and population dynamics of the melon ladybird beetle Epilachna chrysomelina (F.) in Egypt (Coleoptera: Coccinellidae). Agri. Res. Rev. 61(1): 179-191.

Bohlen, e. and J. W. Freidel (1979) Crach programe - Plant protection New Vally, Egypt. Consultancy Mission. 14.02.1979-7.03.1979. German Agency for Technical Cooperation (GTZ), 56 PP.

Chen, L. F.; Z. Q. Lu and S. D. Zhu (1989). Biology of Henosepilachna vigintioctopuntata (Fabricius) and its effective accumulated temperature. Plant Protection. 1: 7-8 
El-Saeady, A. A (1978) Ecological and physiological studies on melon ladybird beetle Epilachna chrysomelina (F.) (Coleoptera: Coccinellidae). PH. D. Thesis, Fac. Of Agric., Al-Azhar Univ., 146 pp.

El-Abdin, A. M. Z.; B. G. Siragelnour (1991) Biological aspects, food preference and chemical control of the cucurbit beetle, Henosepilachna elaterii (Rossi) (Coleoptera; Coccinellidae). Arab J. Plant Protection. 9 (2): 103-110.

Elden, T. C (1991) Influence of photoperiod and temperature on the reproductive diapause of two different geographic populations of the Mexican bean beetle (Coleoptera: Coccinellidae) and their cross progeny .J. Entomol. Sci. 26 (1):109-121.

Fan, Y. Q.; E. Groden and F. A. Drummond (1992) Temperature-dependent development of Mexican bean beetle (Coleoptera: Coccinellidae) under constant and variable temperatures. J. Economic Entomol. 85 (5): 1762-1770.

Gameel, S. M. M. (2004) Eco-Biological studies on the black melon bug, Coridius (Aspongopus) viduatus F. ( Hemiptera:pentatomidae) in the new vally . ph. D. Thesis, Fac. Of Agric., Assuit Univ., 209 pp.

Gameel, S.M.M. and M.A Abdel- Gaid (2007). Realative susceptibility of three cucurbit vegetables to the infestation Epilachna chrysomelina (F.) (Coleoptera: Coccinellidae) at the New Vally - Egypt The $1^{\text {st }}$ International conference on desert cutivation. 27-29 March, Minia Univ. 85-90.

Ghabn, A. A. (1951) Studies on the biology and control of Epilachna chrysomelina (F.) in Egypt (Coleoptera: Coccinellidae) . Bull. Soc. Egypte. 35:77-108.

Patel, K. N.; M. S Purohit (2000) Host preference of epilachna beetle, Henosepilachna vigintioctopunctata (Fabr) Gujarat Agric. Univ. Res. J. 25 (2): 94-95.

Sayed, A. A. and S. M. M. Gameel (2008) Effect of some vegetable cucurbit crops and seasonal plantation on the population densities of Epilachna chrysomelina (F.) (Coleoptera: Coccinellidae) at the New Vally - Egypt. Egyptian J. Agric. Res. 86(3):1053-060

Takeuchi, M.; M. Satoh; K. lijima and M. Tamura (2008) Reproductive diapause in univoltine phytophagous lady beetle, Epilachna admirabilis (Coleoptera: Coccinellidae) in Kanagawa Prefecture, Japan. Japanese J. Appli. Entomol. and Zool. 52 (3) : 142-145. 
Awadalla, S. S. et al.

تأثير درجات الحرارة والعوائل النباتيـة المختلفة على بعض الخصائص البيولوجية لحشرة خنفساء القثاء

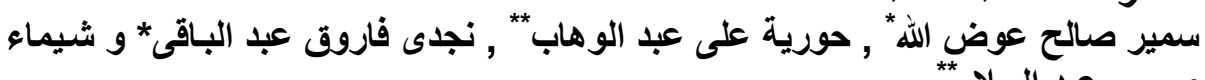
صبرى عبد السلام عزئ

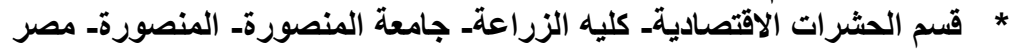

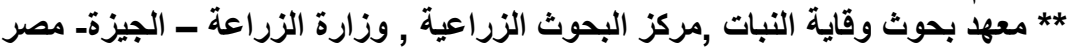

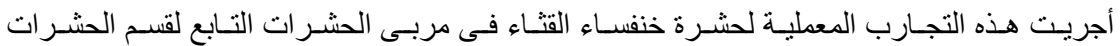

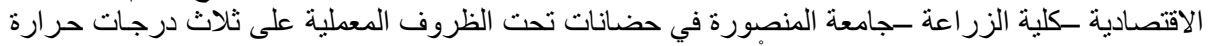

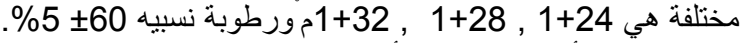

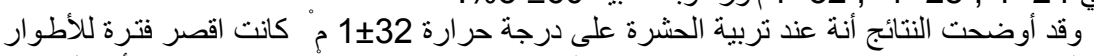

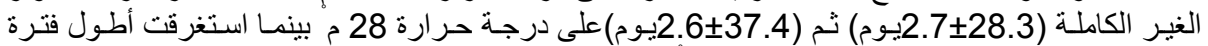

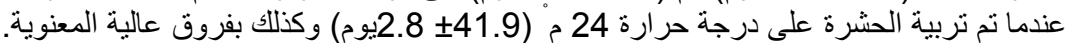

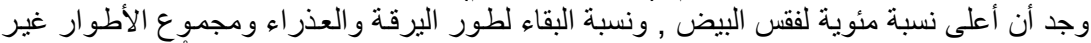

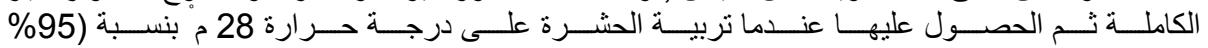

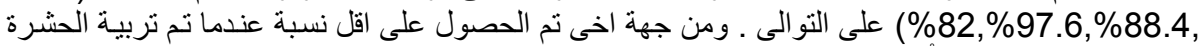

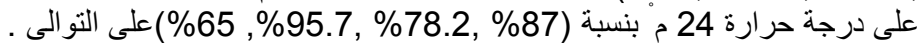

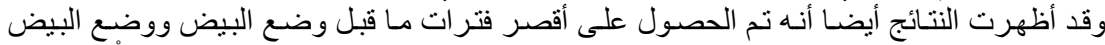

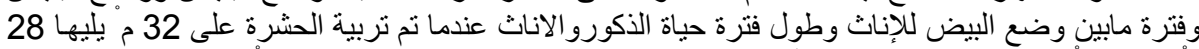

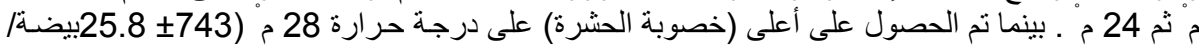

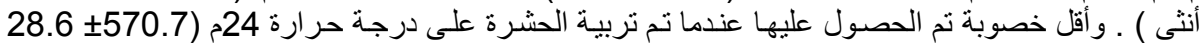
بيضة/ أنثى ) وذلك بفروق عالية المعنوية.

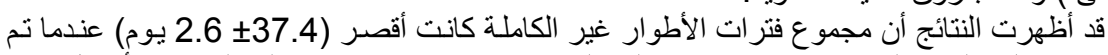

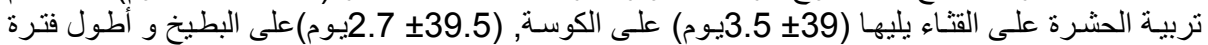

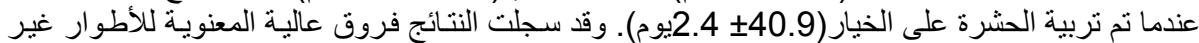
الكاملة عند التربية على عو ائل مختلفة.

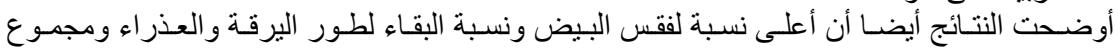

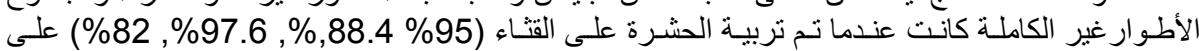

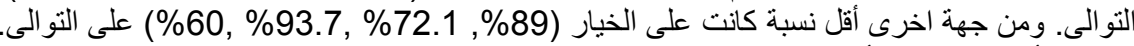

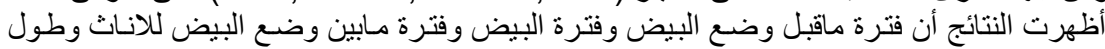

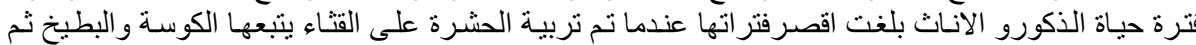

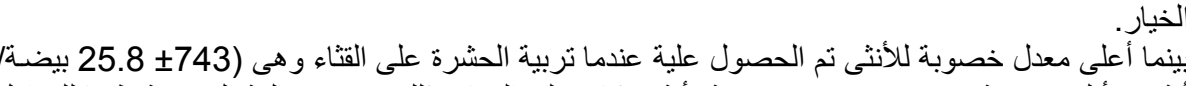

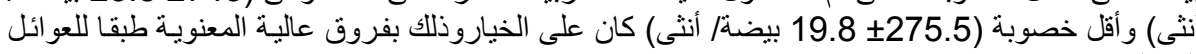
المختلفة

كلية الزراعة - جامعة المنصورة

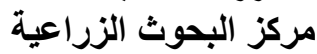

قام بتحكيم البحث

أ. أد / عبد البديع عبد الحميد غانم

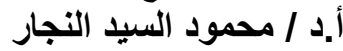

